\title{
初期養生条件がモルタルの疲労およびそれに起因する中性化に及ぼす影響 EFFECT OF CURING CONDITION IN EARLY AGE ON FATIGUE OF MORTAR AND CARBONATION OF FATIGUED ONES
}

\author{
田中享二*, 全 振 煥**, 名和豊春***, 橋田 浩**** \\ Kyoji TANAKA, Jin-hwan JEON, Toyoharu NAWA \\ and Hiroshi HASHIDA
}

\begin{abstract}
Mortar specimens cured at various conditions were first subjected to bending repeated loads, and it was made clear that insufficient cure reduced fatigue resistance of them. Next, fatigue tests that the stress levels are lower than the ones of fatigue rupture were carried out, and the improved scale based on the Gompertz curve was proposed for expressing fatigue of specimens. The effect of curing conditions in early age on carbonation was furthermore studied using the scale, and it was made clear that insufficient cure is also susceptible to their carbonation. Finally, the reason for rapid carbonation of fatigued mortars insufficiently cured was discussed from the view point of changes in pore structure of them.
\end{abstract}

Keywords : Repeated load test, Fatigue, Curing condition, Gompertz curve, Pore structure, Carbonation 繰り返し試験、疲労、盖生条件、ゴンペルツ曲線、細孔構造、炭酸化

\section{1. はじめに}

コンクリートやモルタルは、多数回の繰り返し載荷を受ける部位 に使用されることが多い。これら部位の設計では強度的に十分なゆ とりがとられており、適切な施工と十分な養生がなされていれば、 構造的に危険な状態になることはない。しかしこれら材料は脆性材 料であり、多数回の繰り返し載荷による疲労劣化が予想される。も ちろん実際の建物ではこれらに対して十分なゆとりが持たされて おり、この面で問題になることはまれである。しかし力学的にはそ れほど問題とならない場合でも、耐久性の面では重要となる。繰り 返し載荷により微細構造が変化することは、中性化等の劣化が進行 しやすくなることが想定されるからである。これらに関してはすで に、養生期間を十分にとり十分硬化したコンクリートやモルタルに ついては前報1)で検討した。

ところで現害の構造物の作られ方の実態をみると、綮しい施工期 間の制約のなかでは、実験室で行われるような丁寧な養生ができて いない場合もあり、そのような構造物が現実には多く作られている にも係わらず、養生条件を踏まえての繰り返し載荷が耐久性に及ぼ す影響については、ほとんど関心が払われていない。この観点から 現実のコンクリート施工を考えると、避けることのできない問題で あり、この点に着目した研究が必要である。何故ならば養生が十分
でない場合には、組織が強固ではなく、疲労の影響を受けやすくな り、急速な耐久性低下が㗭念されるからである。そのためには、養 生期間あるいは養生環境が望ましくないなどの、条件が十分ではな い養生状態での試験体についても、疲労性や耐久性低下の諸点を明 らかにしておく必要がある。本研究はこのことを踏まえ、疲労破壊 には至らない範井の疲労蓄積による耐久性低下について、繰り返し 載荷前の材齢や養生条件がどのような影響を与えるかを、明らかに しようとするものである。また前報 ${ }^{1)}$ では十分養生した試験体につ いての疲労蓄積の評価を試みた。これは限定された実験の範囲では 問題はないが、応力水準の低い条件での疲労試験を行った今回の結 果の評価には不十分であることが判明したため、疲労蓄積の評価方 法を見直し、さらに改善をはかることも目的とした。

既往の研究についてであるが、疲労の問題は構造材料として使用 される材料の重要問題であり、古くから研究はなされている。しか し研究のほとんどは疲労破壊に対してなされたものであり、例えば 繰り返し応力の載荷条件に関する研究2)-4)、疲労強度、寿命に関す る研究 ${ }^{(5)-8)}$ である。疲労の影響を受けたものの物性変化に関しては、 研究例はきわめて少なく、コンクリートの組織の変化、細孔構造の

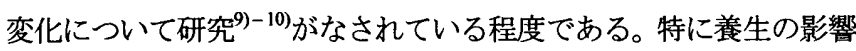
にまで踏み込んだ研究は筆者の知る範囲ではほとんどない。
* 東京工業大学建築物理研究センター- 教授・工博

** 東京工業大学 大学院生.工修

*** 北海道大学大学院工学研究科 助教授 $\cdot$ 工博

**** 清水建設(侏技術研究所工修
Prof, Structural Engineering Research Center, Tokyo Institute of Technology, Dr. Eng.

Graduate Student, Tokyo Institute of Technology, M. Eng.

Assoc. Prof., Faculty of Engineering, Hokkaido University, Dr. Eng.

Research Engineer, Institute of Technology, Shimizu Corporation, M. Eng. 


\section{2. 試験体}

\section{1 試験体の形状と調合}

試験体には水セメント比60\%のモルタル角柱供試験体 $(10 \times 10 \times$ $40 \mathrm{~cm}$ ）を用いた。実用的にはコンクリートが主体となるが、コンク リートには粗骨材が入っており、疲労試験後の分析のしやすさを考 慮してモルタルとした。その調合と物理的性質を表1に示す。

\section{2 養生}

脱型後の養生についてであるが、その耐疲労性に及ぼす影響を調 べるため、4種類の養生方法によった。まず十分養生された条件と して、3ヶ月の水中養生、標準的な養生として28日水中養生、不十 分な養生として、水中1日と、さらに実際の工事の状況を考慮し、 材㱓初期では型枠内で養生されることを想定した7日間の封かん養 生とした。養生後は恒温室内（温度: $20 \pm 2^{\circ} \mathrm{C} 、$ 湿度: $60 \pm 10 \%$ R.H.）に 1ヶ月放置し、乾燥させた。これらの試験体の養生工程を図1に示す。 ただし、この中には実験スケジュールの関係で、10日程度乾燥期間 の延びたものもあるが、1ヶ月以上の乾燥では強度変化に及ぼす影

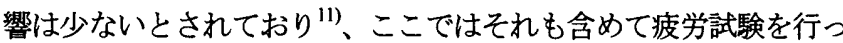
た。

\section{3 曲げ強度}

所定の期間乾燥させた後で、静的曲げ強度試験を行った。試験は JIS A1106に準じた3等分点載荷法によった。この時、試験体下面に 貼り付けたストレインゲージにより伸びひずみも測定した。測定結 果を図 2 に示す。養生条件、期間の影響は顕著であり、養生期間が 長くなるに従って強度が高くなっている。

\section{3. 破壊までを対象とした繰り返し試験}

\section{1 試験の概要}

繰り返しは3等分載荷片振り曲げとした。試験には油圧制御型繰 り返し試験機を使用した。負荷応力の上限值は静的曲げ強度の 0.8 、 0.7、0.6の3段階とし(一部は0.9も追加)、下限值はゼロとした。周波 数は $10 \mathrm{~Hz}$ とし、疲労破壊までの繰り返し回数を調べた。試験体数は 原則として3本であるが、疲労試験は試験体の欠陥の影響が特に大 きく、わずかな欠陥でも破壊までの繰返し回数を激减させる。その ため極端な測定值はデータとして採用しなかった。

\section{2 試験結果}

繰り返し破壊試験の結果を図3に示す。ここでの実験では、負荷 する応力比（ $\sigma / f ）$ を一定にしているため、曲げ強度の大きい試験 体では負荷させる応力も大きくなっている。当然のことながら負荷 応力のレベルが高くなるに従って、破壊までの繰り返し回数は减少 している。この曲線群は関数を用いた実験式で表すことができそう であり、前報 ${ }^{1)}$ では多くの疲労研究での数式化に利用されてる（1） 式で表される単純な指数関数式での表現を試みた。

$\sigma / f=1-\mathrm{a}(\log \mathrm{N})^{\mathrm{b}}$

ここに, $\quad \sigma:$ 曲げ応力 $\left(\mathrm{N} / \mathrm{mm}^{2}\right)$

$f:$ 最大曲げ応力 $\left(\mathrm{N} / \mathrm{mm}^{2}\right)$

$\mathrm{N}:$ 絽り返し回数

a, b : 係数

この式は部分的には非常に適合性の良い数式であったが、適用上
表1 モルタル試験体の調合

\begin{tabular}{c|c|c|c|c|c|c}
\hline \multirow{2}{*}{$\begin{array}{c}\text { 水セxン比 } \\
(\%)\end{array}$} & \multirow{2}{*}{ セxント : 砂 } & \multicolumn{3}{|c|}{ 単位重量 $\left(\mathrm{kg} / \mathrm{m}^{3}\right)$} & \multirow{2}{*}{$\begin{array}{c}\text { フ口一值 } \\
(\mathrm{mm})\end{array}$} & $\begin{array}{c}\text { 空気量 } \\
(\%)\end{array}$ \\
\cline { 3 - 6 } & & 水 & セxン & 砂 & & \\
\hline 60 & $1: 3.7$ & 250 & 417 & 1544 & 183 & 5.3 \\
\hline
\end{tabular}

•セメント:普通ポルトラントセメント(密度: $3.16 \mathrm{~g} / \mathrm{cm}^{3}$ )

·細骨材: 静岡県沢岡陸砂(密度: $2.62 \mathrm{~g} / \mathrm{cm}^{3}$ 、吸水率: $1.27 \%, F M: 2.8$ )

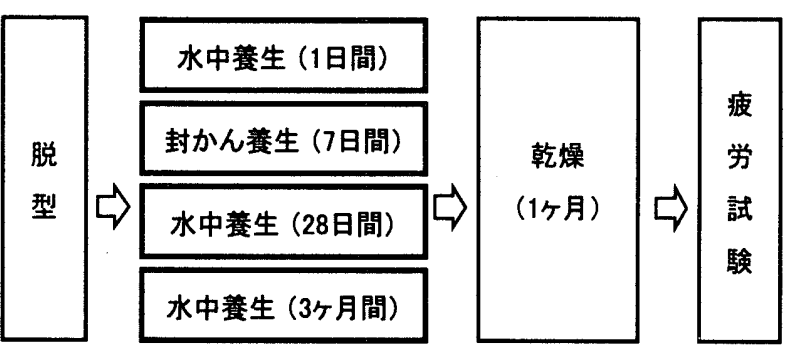

図1 試験体の養生条件

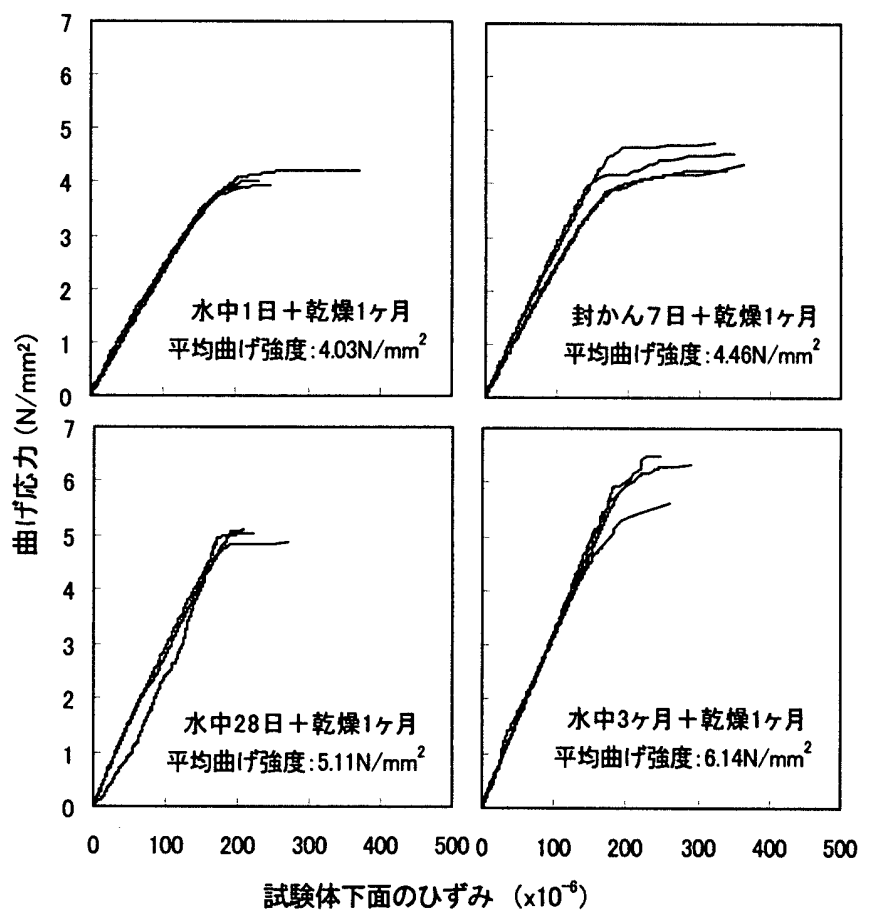

図2 各養生条件下での曲げ強度試験の結果

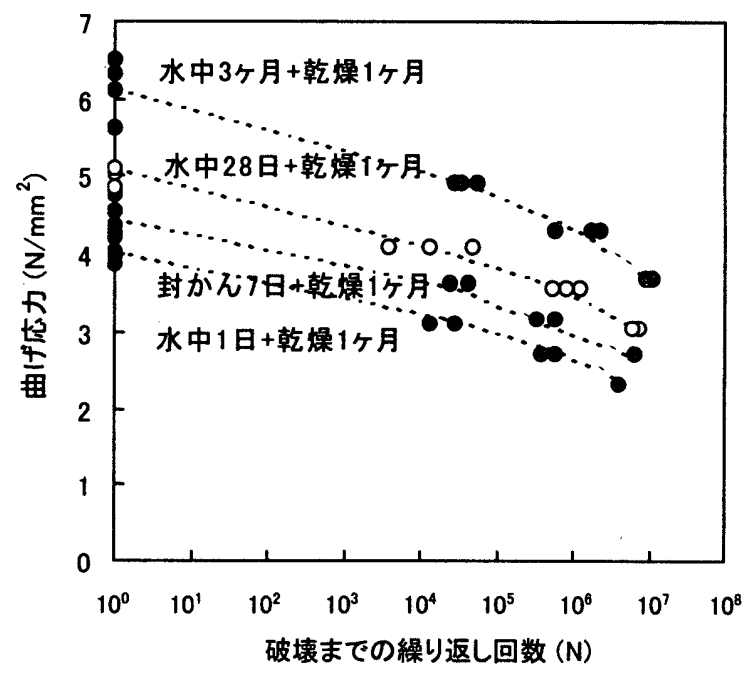

図3 破壊までの疲労試験結果 
の限界があった。すなわち応カレベルの高い領域での疲労試験のみ 限定すれば問題は生じないが、低応カレベルにまで拡張すると、適 合性の低下が予想されるからである。例えば応力の生じていない $\sigma$ =0の場合を考えると、全く疲労していないにもかかわらず、破壊 までの繰り返し回数を持ち、必ず疲労破壊するという論理的矛盾を もつからである。このことは低応力時の近似性がないことを予想さ せるものであり、ここで行った低応力レベルも含む疲労現象を検討 するためには、これらの矛盾を持たない数式化を図る必要がある。

この条件を満たす、すなわち応力レベルが低い時には繰り返し回 数が急速に増加し、そして $\sigma=0$ の時、Nが無限となる性質をもつ代 表的な関数式として、ゴンペルツ曲線とロジスティック曲線があ り、ここではこの2つの曲線を利用して、疲労曲線を作成し、その 適用の可能性を調べた。両式を利用した疲労曲線は(2)、(3)式で表さ れるが、これを用いて近似した結果を図4に示す。

$$
\begin{aligned}
& \text { ゴンペルツ曲線を基にした時の疲労曲線 } \\
& \sigma / f=1-\mathrm{Ca} \mathrm{a}^{\mathrm{b}^{(\log \mathrm{N})} \ldots \ldots \ldots \ldots \ldots \ldots \ldots \ldots \ldots}
\end{aligned}
$$

ロジスティック曲線を基にした時の疲労曲線 $\sigma / f=1-\mathrm{C} /(1+\mathrm{a} \exp (-\mathrm{b} \log \mathrm{N}))$

ここに $\sigma:$ 曲げ応力 $\left(\mathrm{N} / \mathrm{mm}^{2}\right)$

$f:$ 最大曲げ応力 $\left(\mathrm{N} / \mathrm{mm}^{2}\right)$

$\mathrm{N}:$ 繰り返し回数

$\mathrm{C}, \mathrm{a}, \mathrm{b}:$ 係数

この係数の中でCについてはその値が養生条件の差が小さかった ので平均値をとり同じ数値とした。図4に示すとおり両式とも比較 的良く実験結果と適合しているが、比較するとゴンペルツ曲線を基 にした疲労曲線の方が実験結果との適合性が多少良いように思わ れる。そのため以後はこの式を用いて検討を進めることとした。

\section{4. 破壊に至らない範囲での疲労蓄積の評価 \\ 4.1 試験の概要}

ここでは試験体を破壊までは至らせずに、疲労させることだけを 目的として疲労試験を行った。試験は同じく片振り曲げである。負 荷応力レベルは、前項の疲労破壊試験結果を参考とし、負荷応力レ ベルを破壊時の曲げ強度に対して、0.2、0.5、0.8の3段階とした。疲 労試験は各々疲労破壊しない範囲とし、最大 1000 万回までの範囲で 疲労の蓄積程度を変化させることを意図した、表 $2 に$ 示す繰り返し 回数で試験を行った。

\section{2 疲労蓄積の評価}

前報では疲労蓄積を、疲労進行度としてその評価を試みたが、こ れは先に述べたように応力レベルの高い範冊でのみ適用できた尺 度であり、低応力繰り返し負荷も含めた範囲での適用はできない。 従って新たな評価尺度が必要である。そのためここではさらに、す ベての応カレベルに対してもできる疲労評価尺度を検討した。

先のゴンペルツ曲線を基にした疲労破壊曲線は、各繰り返し回数 ごとに負荷しうる疲労破壊応力の限界值を表すものであり、その範 囲内ならば疲労蓄積は負荷される応力の大きさの影響を受ける。こ れが負荷された応力に比例すると仮定すれば、各繰り返し回数ごと
に疲労蓄積度を次式で計算でき、等価疲労度曲線(疲労の蓄積が同 程度と推定される曲線)を求めることができる。

\begin{tabular}{|c|c|c|c|}
\hline \multirow{2}{*}{$\begin{array}{c}\text { 応カレベル } \\
(\sigma / f)\end{array}$} & \multicolumn{3}{|c|}{ 繰り返し回数 } \\
\hline & $10^{3}$ & $10^{5}$ & $10^{7}$ \\
\hline 0.2 & 0 & 0 & 0 \\
\hline 0.5 & 0 & 0 & 0 \\
\hline 0.8 & 0 & - & - \\
\hline
\end{tabular}

$$
\begin{aligned}
& \sigma / f=\mathrm{m}\left(1-\mathrm{Ca}^{\mathrm{b}^{(\log \mathrm{N})}}\right) \\
& \text { ここに } \mathrm{N} \text { : 繰り返し回数 } \\
& \mathrm{m} \text { : 疲労度 }(0 \sim 1) \\
& \mathrm{C}, \mathrm{a}, \mathrm{b}: \text { 係数 }
\end{aligned}
$$

表2. 繰り返し試験における負荷応カレベルと繰り返し回数

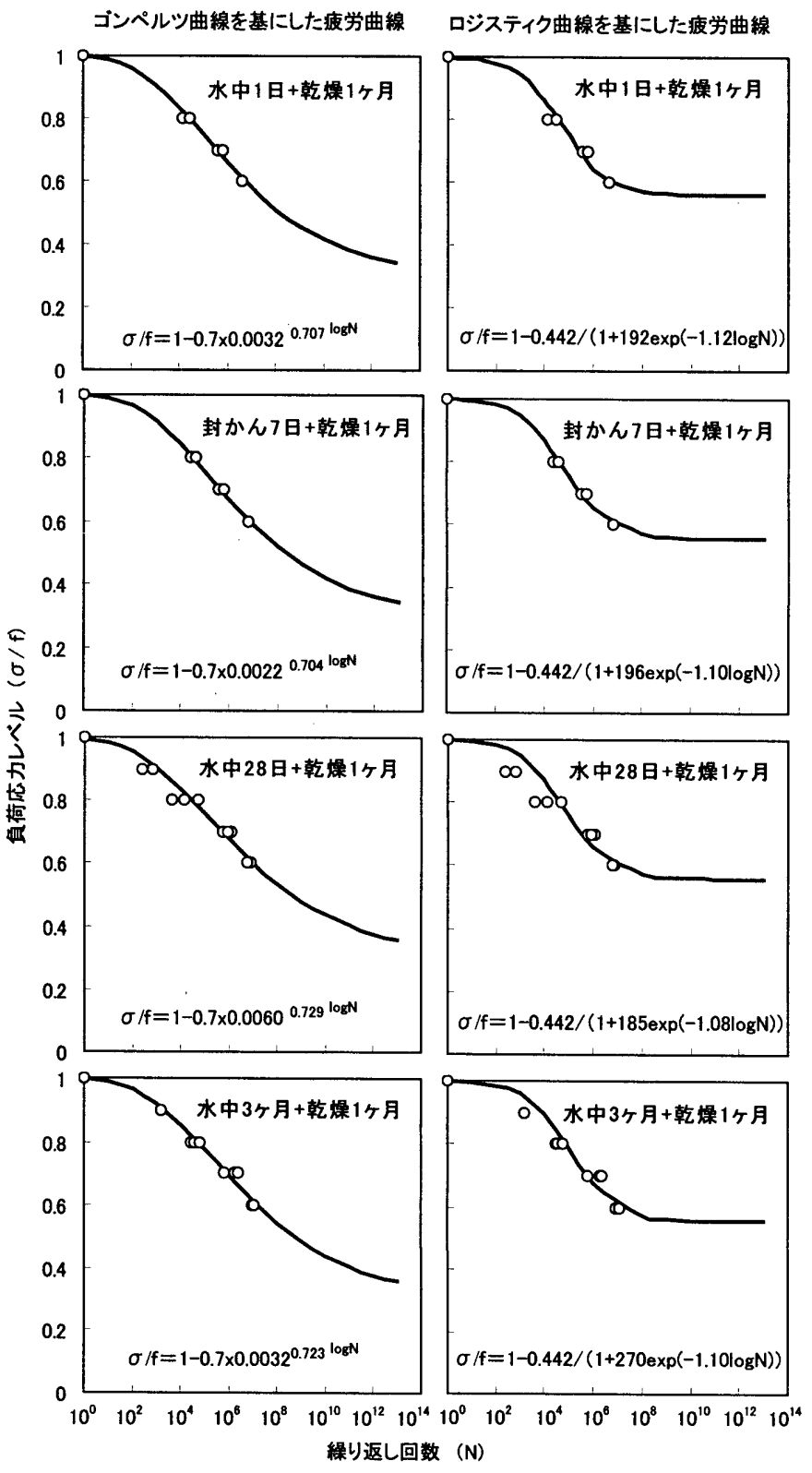

図4 ゴンペルツ曲線、ロジスティック曲線を基にした疲労破壊曲線 
この考え方により計算された等価疲労度曲線を図5に示す。 $\mathrm{m}=1$ の場合はゴンペルツ曲線を基にした疲労破壊曲線そのものであり、 この値に到達した時には疲労破壊する。それに満たない領域におい ては、疲労が蓄積されているが破壊には至らない。そして疲労回数 が増加、もしくは負荷される応力レベルが高くなれば、疲労度は上 昇し疲労限界に近づくことになる。これにより応力レベルの低い場 合の疲労蓄積が適性に評価されることになり、前報での疲労進行度 では評価出来なかった低応力の疲労も含む、広い範囲での評価が可 能となる。この式により計算された各繰り返し試験条件ごとの疲労 度を図6に示す。図中の数字が疲労度を表す。

\section{5. 疲労の蓄積が中性化に及ぼす影響}

\section{1 中性化試験の概要}

耐久性に及ぼす疲労の影響を調べる目的で、所定の繰り返し回数 の載荷を行った後で、促進中性化試験を行った。試験には図7に示 すように、繰り返し載荷を受けた試験体を中央部で二等分した一方 （残り半分は細孔構造測定に使用）を用いた。上下の載荷面からの み炭酸ガスを侵入させるようにするため、2面のみを開放面とし、 他の4面をエポキシ樹脂パテで密封した。この試験体を中性化促進 環境 $\left(\mathrm{CO}_{2}\right.$ ガス濃度 $\left.10 \% 、 20^{\circ} \mathrm{C} 、 60 \% \mathrm{RH}\right)$ に2週、4週、8週間暴露 した。所定の時間経過後、試験体の中央部分にそって割裂させ、 $1 \%$ フェノールフタレイン液を噴霧した。試験体数は2本であり、測定 は試験体の下面に沿って $5 \mathrm{~mm}$ 間隔ごとに、赤色域までの梁さを測定 した。

\section{2 中性化の測定結果}

中性化深さは大きな引張り繰り返し力が作用したと考えられる 試験体2本の中央部分 $50 \mathrm{~mm}$ の領域での平均値で、各養生条件ごとに 図8に示す。全く繰り返し載荷を受けていない健全試験体に比べて、 疲労を受けたものでは中性化速度が大きくなっている。また中性化 試験時間が長くなるに従って、中性化媣さは深くなる傾向が見られ る。この中性化促進時間と中性化深さとの関係を定量的に調べるた め、促進材齡 $2 、 4 、 8$ 週の結果を用いて中性化速度係数を求めた。 中性化は一般に時間の平方根にほぼ比例する ${ }^{2)}$ と言われており、こ こでもその考えに従った（5）式により、材踚2、4、8週のデータを 回帰して中性化速度係数を求めた。

$\mathrm{D}=\mathrm{K} \sqrt{\mathrm{t}}$

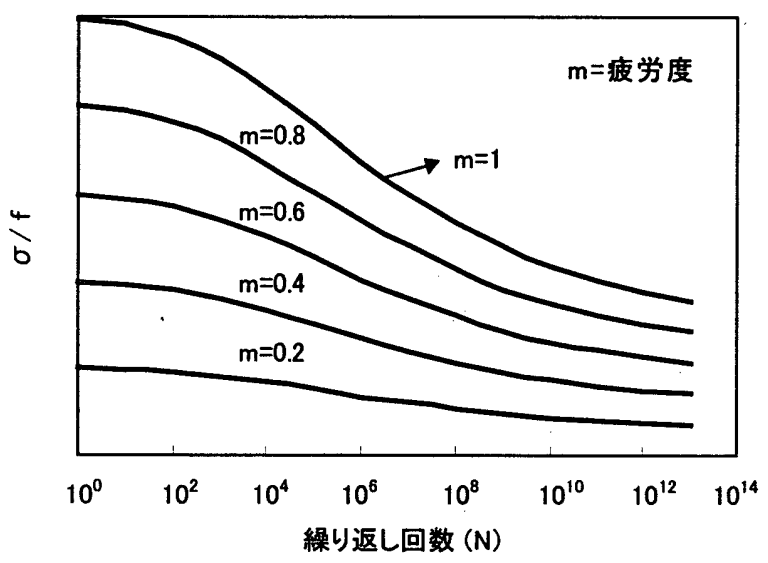

図5 等価疲労度曲線
ここで $\mathrm{D}:$ 中性化深さ、mm

$\mathrm{K}:$ 中性化速度係数

$\mathrm{t}$ : 時間、week
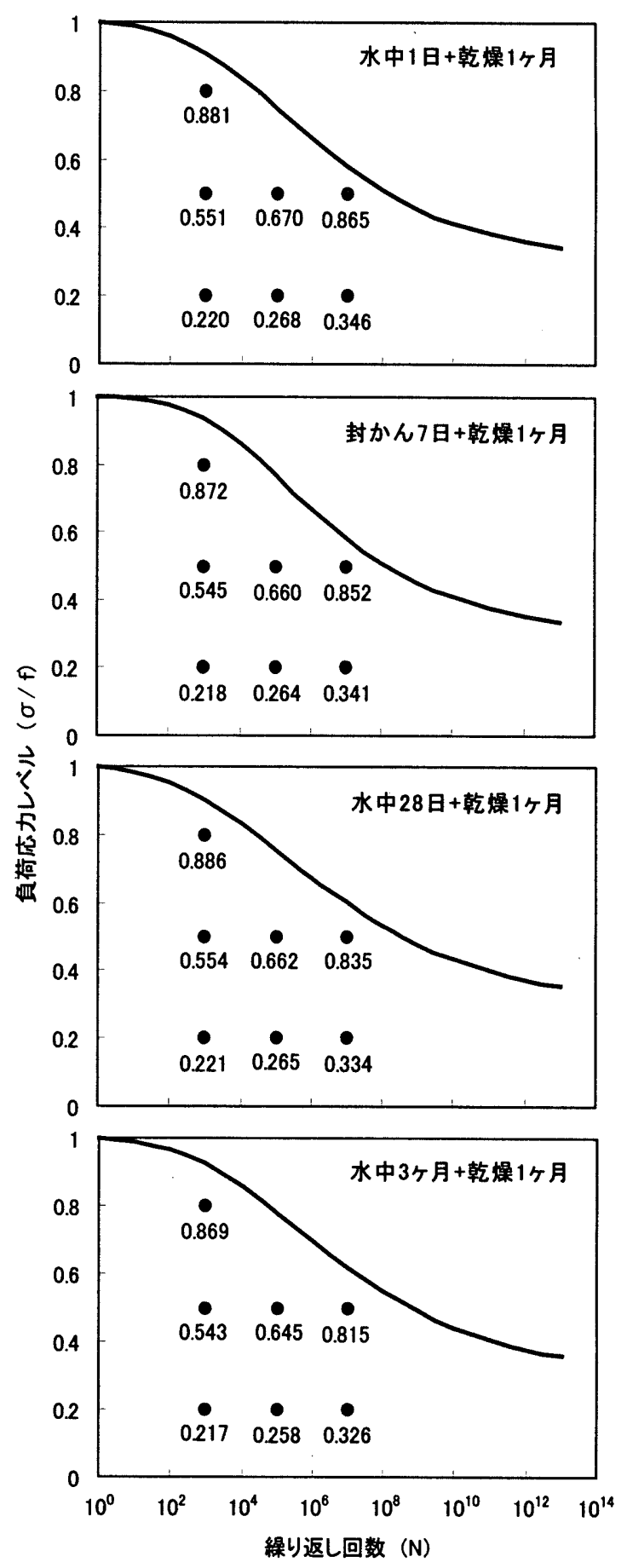

図6 各繰り返し試験条件ごとの疲労度(図中、数字が疲労度を示す)

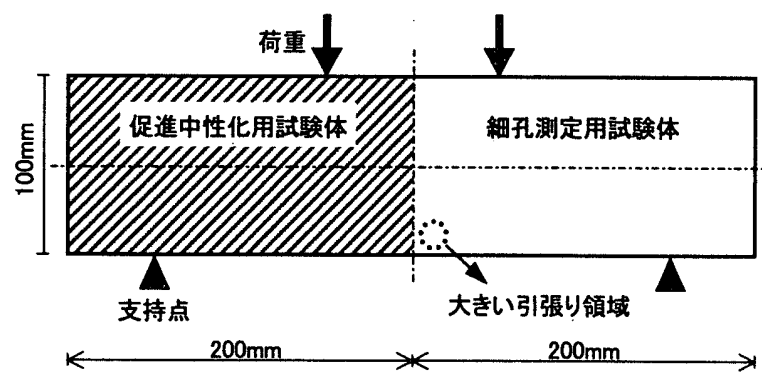

図7 促進中性化用、細孔測定用試験体と試験片探取位置 


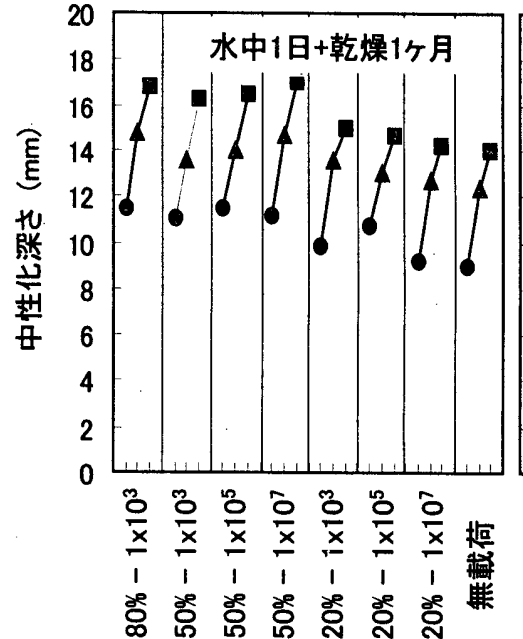

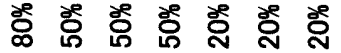
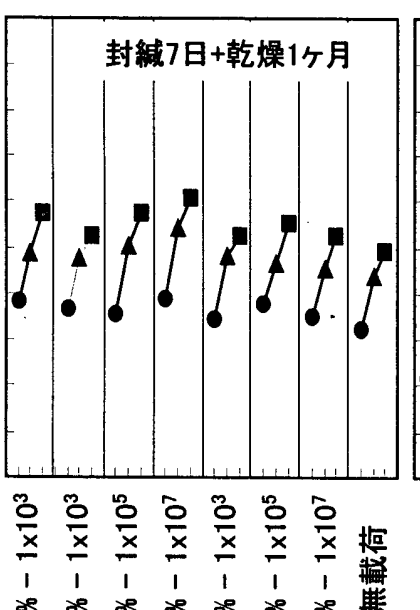

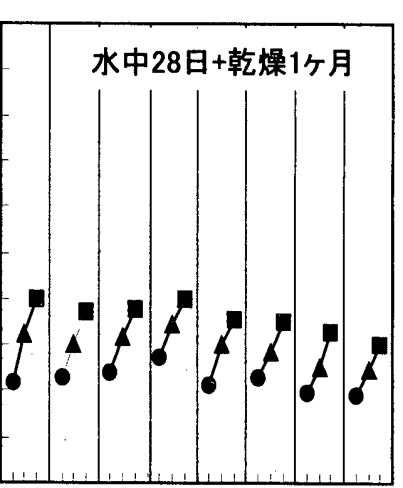

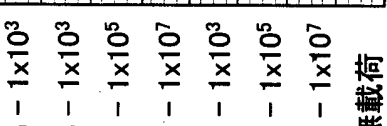

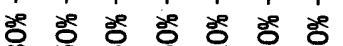

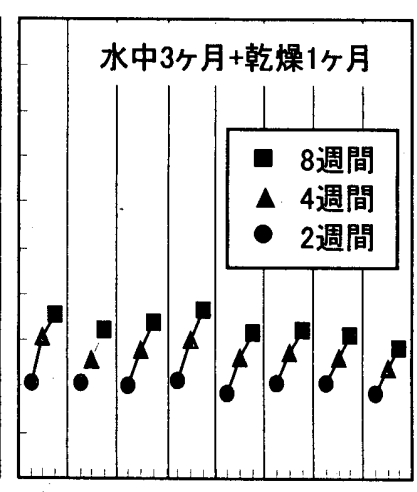

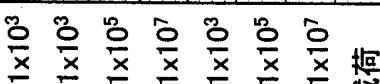

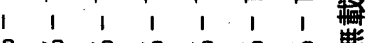

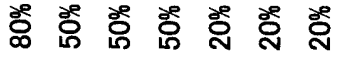

載荷条件

図8 各繰り返し試験条件での中性化深さ

5.3 中性化に及ぼす疲労と養生条件の影響

\section{(1) 疲労の影響}

各試験体ごとに得られた中性化速度係数を、疲労度ごとにプロッ トし、図9に示す。多少ばらつきのある部分もあるが、疲労が進行 にするに伴い、中性化速度が大きくなる傾向が見られる。

\section{（2）養生期間の差}

養生期間の影響もやはり図9に示されるが、その中性化速度に及 ぼす影響も明膫である。養生期間が短い場合は中性化速度が大きく なり、十分な養生の場合は中性化速度が低下する。

またいずれも疲労が進行するに伴い中性化速度が上昇している が、その傾きに着目すると、十分な養生の場合は多少緩くなってお り、疲労の影響が少なくなる傾向が示されている。中性化は耐久性 評価の基本尺度であり、この観点からは養生が不十分な場合には耐 久性が低下していること、また疲労の影響も受けやすくなる傾向に あることが示されているものと考えられる。

\section{6. 養生条件と疲労が中性化に及ほす影響の考察 6.1 細孔構造の変化}

疲労に及ぼす養生条件の影響を考察するために、それら試験体の 細孔構造を調べた。繰り返しを受けた試験体の中央部で二等分した 残りの一方を用い、前述の図7に示すように、大きな引張り力が加 わる試験体下側の中央付近から小片を採取した。

細孔の測定には、水銀圧入式ポロシメーター（マイクロメリテッ クス社製ポアサイザ9310）を使用し、細孔直径0.003〜 400 $\mu \mathrm{m}$ 範 囲で細孔容積を測定した。测定結果は文献 ${ }^{13)}{ }^{14)}$ を参考として、と りあえず3つの領域、毛細管より小さい領域 $(0.003 \sim 0.01 \mu \mathrm{m})$ 、毛 細管領域 $(0.01 \sim 10 \mu \mathrm{m})$ 、毛細管より大きい領域 $(10 \sim 400 \mu \mathrm{m})$ に区分し、それらと疲労度との関係を調べた。図10に各養生条件ご とに疲労度と区間細孔ごとの累積細孔量の関係を示す。疲労の進行 に伴い総細孔量はわずかではあるが増加する傾向が見られる。この 場合も養生条件の影響が顕著であり、養生が不充分な場合は全空隙 容積も大きく、また大きい細孔径領域の容積も多くなっている。一 方十分な養生の場合は細孔量が少く、緻密な組織になっていること がうかがえる。

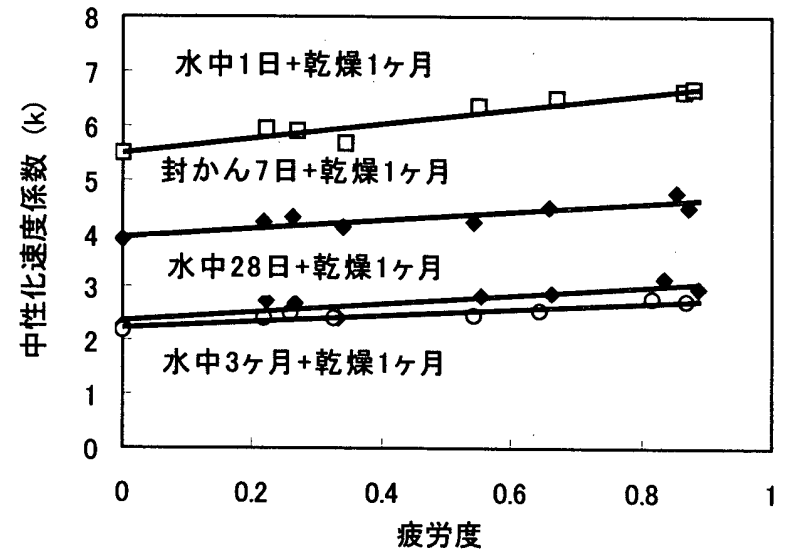

図9 疲労度と中性化速度係数の関係

6.2 中性化と細孔構造との関係

これらをさらに耐久性の観点から見た時、中性化がどの細孔領域 の影響を強く受けているのかを検討する。そのため前述の各細孔径 ごとの区間累積細孔量と中性化速度との関係を調べ、図11に示す。 細孔領域別に見ると毛細管領域の細孔量と中性化速度との関係は、 非常に高い正の相関が見られている。すなわち不充分な養生及び度 労の影響による中性化の上昇は、毛細管領域の空隙の増加に起因す ると考えられる。

また毛細管より小さい領域では負の相関が見られているが、これ はデータが養生条件に塊状に分散していることから判断して、充分 な養生となるに従い組織が緻密化し（そのため毛細管より小さい領 域の細孔が増加している）中性化速度が低下したものである。毛細 管の大きい領域に関しては細孔量と中性化速度との関係はほとん どなく、この領域の細孔は中性化速度にはほとんど影響を与えてい ないと思われる。

\section{7. 結論}

耐久性の観点から、疲労およびそれに及ぼす養生条件の影響を調 ベた本研究の結論をまとめると以下の通りである。

1）前報の疲労度の適用上の限界を拡張するために、ゴンペルツ 曲線を基にした疲労曲線を用いて、低応力領域までに適用可能な疲 

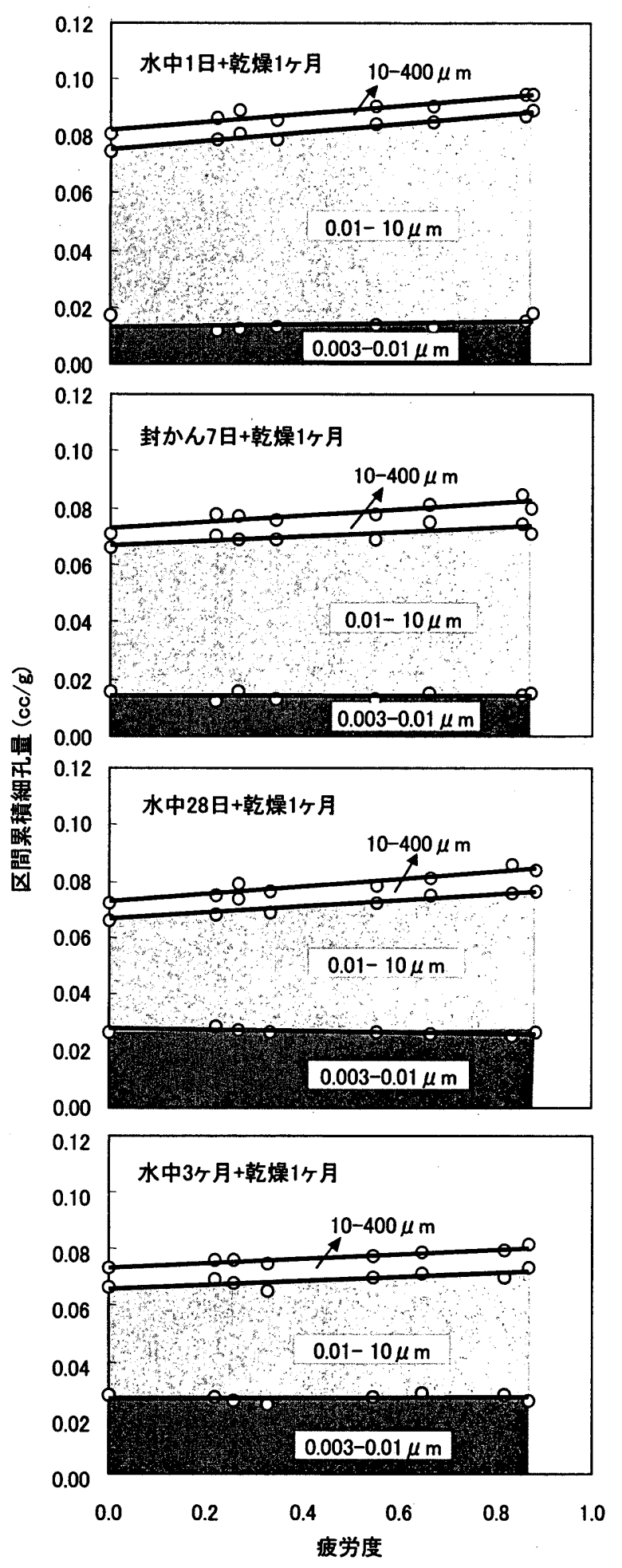

図10 各養生条件ごとの疲労度と区間累積細孔量の関係

労曲線及ひ度労度を提案した。

2）養生条件の影響は顕著であり、養生が不十分な場合には疲労 の影響を受けやすくなること、また中性化速度も速くなり、而久性 上脆弱化することを明らかにした。

3）それらの原因は細孔構造の変化、特に毛細管領域の空隙の増 加によると推定された。

本研究は文部省科学研究費補助金基盤研究(c)「低応力繰り返し載荷 を受けたコンクリートの細孔構造の変化と長期而付久性」によりました。
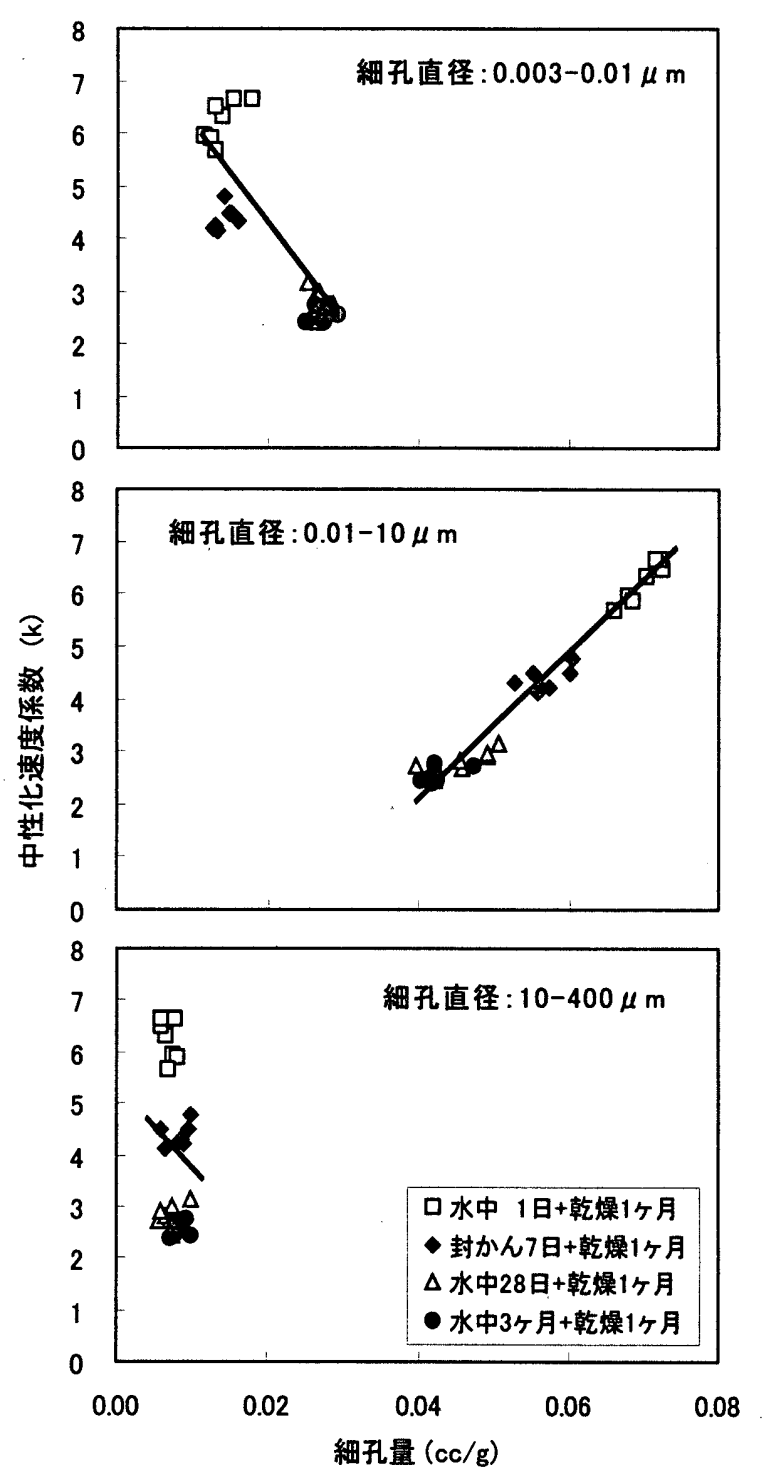

図11 細孔量と中性化速度との相関関係

参考文献

1) 田中享二、全振煥、名和豊春、橋田浩：繰り返し曲げ荷重を受 けたコンクリートとモルタルの細孔槽造の変化と中性化、日本建 築学会構造系論文集、2000.12、No.538、pp.15-19。

2) Kesler C.E.:Effect of Speed of Testing on Flexural Strength of Plain Concrete; HRB Proceedings, Vol.32, pp.251-258, 1953

3) Ballinger C.A.: Cumulative Fatigue Damage Characteristics of Plain Concrete; Highway Research Record, No.370, pp. 48-60; 1971

4) Hsu,Thomas. T. C. 、"Fatigue of Plain Concrete" ACI, Proceedings Vol.78, No.4, July-August pp. 292-305. 1981,

5)松下博道: コンクリートの圧縮疲労寿命に及ほす最小庶力の影 響 ; 第32回土木学会年次学術講演梗概集、第5部、p.282, 1977

6) 松下博道、近田孝夫：コンクリートの疲労寿命分布とS-N曲線; セメント技術年報、XXX, pp.373-376, 1976

7) F.S.Ople and C.L.Hulsbos: Probable Fatigue Life of Plain Concrete with Stress Gradient; J. of ACI, Jan, Vol.63, No.1, pp.59-82, 1966

8) 坂田憲次、木山英郎、西林新蔵: 統計的処理によるコンクリート の疲労寿命に関する研究、士木学会誌、第198号、pp.107-114, 1972

9) 小柳 拾、西谷幸男、六郷恵哲、日下部史明：載荷履歴を受けた コンクリートの組織変化について；セメント技術年報、X X VII 、 pp.207-210, 1976

10) B.Zhang: Relationship between pore structure and mechanical properties of ordinary concrete under bending fatigue; Cement and Concrete Research, Vol.28, No.5, pp.699-711, 1998

11) W.H.Price: Factors Influencing Concrete Strength; Journal of ACI, Vol.47, pp.417-432,1951

12) Kondo,R., Daimon, M., and Akitba, T. :Mechnisim and kinetics of carbonation in hardened concrete; 5th International Symposium on the Chemistry of Cement, Vol.3, pp.402-408, Tokyo, 1968

13) H. Uchikawa, S. Uchida, S. Hanehara:ILCEMENTO. Vol.88, pp.67-90, 1991

14) P.Kumar Mehta, Paulo J. M. Monteiro:Concrete, Structure, Prooerties and Material, $2^{\text {nd }}$, Prentice-Hall, pp.26-29 